\title{
EkoMiasto\#Gospodarka
}

Zrównoważony, inteligentny i partycypacyjny rozwój miasta

pod redakcją

Aleksandry Nowakowskiej

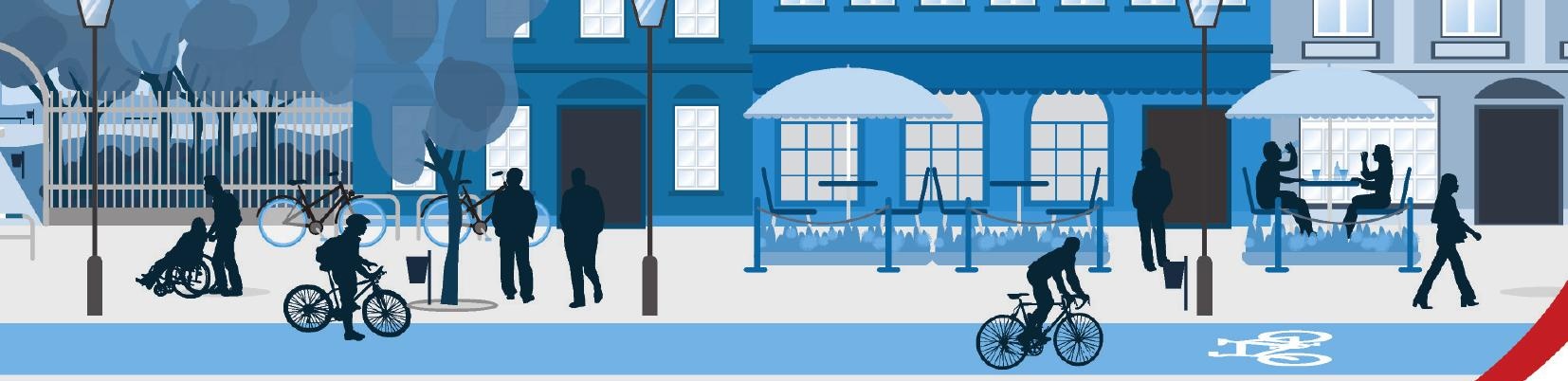


http://dx.doi.org/10.18778/7969-968-1.09

tukasz Arendt*

Iwona Kukulak-Dolata**

\section{LABOUR MARKETS IN BIG CITIES}




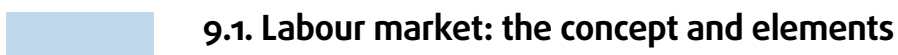

\subsubsection{Labour and labour market}

The labour market is one of the market segments, which operates alongside the markets of land, commodities services, as well as the money and capital markets. Every market is characterised by certain transactions taking place between the buyers and sellers, which concern specific goods. In the case of the labour market the buyer's role belongs to employers, while the sellers are the employees representing individual households. The subject matter of transactions in this case is human capital, understood as a service provided in the form of labour [Jarmołowicz, 2007, p. 37]. Such an interpretation of the subject of the transaction implies that labour is not an ordinary commodity. The following are decisive for its specificity:

- labour cannot be separated from a human being, who is its source and owner, while in the case of any other commodity we can easily separate and transfer the ownership;

- labour contains spiritual and intangible elements;

- labour is not a factor that can be used up or worn out. People offering their work use the qualifications and skills, which over time can develop further thanks to their usage;

- people offering labour differ in terms of the quality of the human capital (skilIs, knowledge, attitude towards work, etc.), which means that two identical transactions cannot be found on the labour market;

- there is no relation between the quantity of work and its price, unlike in the case of other commodities traded in other segments of the market [Jarmołowicz, Knapińska, 2005, p. 13].

Labour performs certain functions. For the employer (the buyer), labour is yet another factor of production. For those who sell it, labour performs an economic function as a source of income, which decides about the households demand for goods and services. Additionally, labour performs also a social function, because it enables self-realization of the employees.

In compliance with the above considerations, it is accepted that the labour market is the place of interaction between two basic market categories - namely labour supply and labour demand. This interaction results in arrangements relating to the size and terms of the transactions, in particular concerning the price, which takes the form of a wage [Kryńska, Kwiatkowski, 2013, p. 11]. In this case, the wage will constitute the cost for those, who buy the labour services, while its level will provide information on the price of this production factor. In turn, for those, who sell labour, their earnings determine the quality of life. Therefore, individuals selling their labour are interested in the highest possible level of salaries or wages, whereas the buyers will naturally tend to minimise their levels.

Labour market analyses distinguish between the nominal and the real wages. The nominal wage indicates the amount of money an employee receives for the work provided in a given period of time (usually a month). The real wage in turn, provides information on the quantity of goods or services which can be bought with the nominal earnings. The real wage defines the purchasing power, which can be calculated by dividing the nominal wage by the consumer price index [Kryńska, Kwiatkowski, 2013, p. 14]. Nominal earnings are used in analyses for comparing their levels across certain groups of employees, professions, regions or local labour markets in a given time span. In this case, it is important that the levels of nominal wages are compared for the equivalent periods, when the conditions of sales or purchase of goods are 
comparable. Real wages, in turn, are used for analytical purposes when in consecutive periods the levels of nominal earnings and the levels of commodity and services prices may vary.

Labour markets can be analysed in a number of various dimensions, however the key importance is attached to the spatial dimension, embracing:

- national labour market;

- regional labour markets;

- local labour markets.

The above are delimitated against various criteria [see Kryńska, Kwiatkowski, 2013, p. 17]. In many analyses, because of statistical data availability, the NUTS classification (Nomenclature of territorial units for statistics/Nomenclature des Unités territoriales statistiques) is used.

\subsubsection{Labour supply and labour demand}

A labour market is the place where the labour supply and demand are confronted. The labour supply is the amount of labour offered for sale. Its size results from the decisions taken by persons representing individual households, available and ready to work. The labour supply can be presented as the total and the actual labour supply. The total labour supply includes both those already working and the unemployed, whereas the actual labour supply includes the unemployed willing to undertake a job and seeking work via intermediaries, such as labour market institutions, or outside of them. In quantitative terms, labour supply consists of the number of persons employed, unemployed and those seeking work, as well as, the available time they offer to the labour market [Zieliński, 2012, p. 9].

The basic sources of labour supply can be found in the demographic processes in particular the population growth rate, which effects on the labour market occur with the delay of ca. 20 years. For labour market supply there are two important elements: the size of the population and its economic age structure (the population at working, pre-working and post-working age). The basic part of labour supply will be determined by the size of the population at the working age, offset with the number of those at the post-working age but still working and those already working, despite not having reached the working age.

The working-age population may be divided into the economically active and inactive. The economically active population (also called the labour force) includes all persons at the working age, who are able to work and ready to undertake employment under typical conditions (in particular wage-related ones) characteristic of a given economy. The rest of the working age population are, in turn, economically inactive (out of the labour force). In a dynamic economy it is quite rare for all the labour force to work. This leads to another division between the employed (persons who are hired or self-employed) and the unemployed (those, who looked for jobs but could not find them) (Fig. 9.1). Labour supply depends on the number of persons at the working age and the size of labour force. The larger the share of persons at working age and these economically active in the labour force, the larger the labour supply.

The volume of labour supply will be also influenced by the balance of migrations: external (related to the influx of employees from abroad) and internal, resulting from population flows between individual regions or local labour markets. Nowadays, internal migrations play an important role in shaping the labour supply in big cities, where the local labour markets absorb certain surplus of work force originating from other areas. 


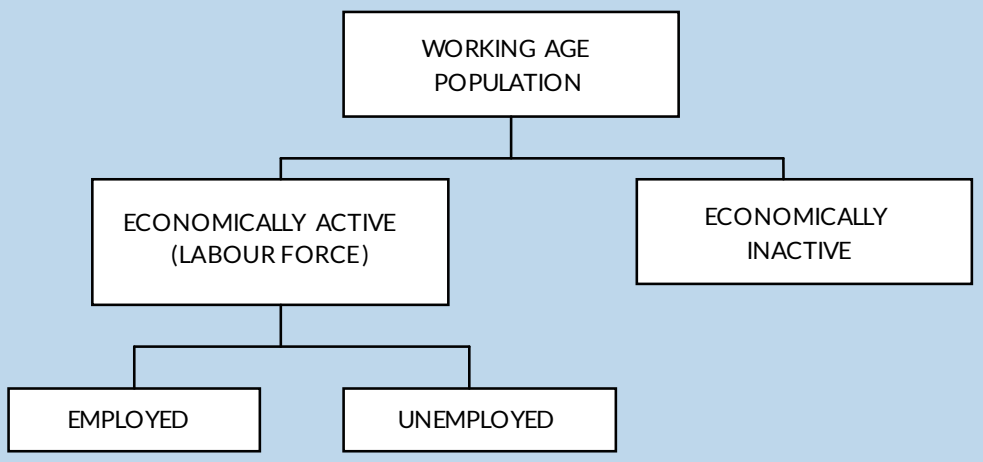

Source: Kwiatkowski, 2002, p. 27.

When analysing the level of labour supply, one cannot neglect the possibility of enhancing labour market participation of the economically inactive persons (e.g. persons who are not working but are involved in running the households or caring for the dependents, as well as, pensioners, students, etc.). The amount of labour supply is influenced by a number of factors, deriving from the socio-economic policy of the state. Therefore, the solutions influencing the wages, social security and social assistance or the educational systems play an important role in shaping labour supply. In the case of Poland's economy, the wage level seems to be the most important factor determining the volume of the labour supply. This factor should be analysed from the perspective of two effects. Firstly, the substitution effect, which causes that the pay increase may motivate individuals to intensify their economic activity, undertake employment and resign from their leisure time, thus leading to the increase of labour supply. Secondly, the income effect of pay increase means that people with higher income will tend to value their leisure time more and - as a consequence - they will be ready to limit their working time. In practice, however, the impact of the substitution effect is by far larger than that of the income effect, which means that a pay rise seems to be a stronger stimulus for the increase of the labour supply. The level of labour supply depends also on a number of cultural and institutional factors. The latter consist of the legal regulations concerning the statutory working time, retirement age or compulsory schooling period. Under current conditions one should not neglect the variable level of work intensity. The labour supply is also characterised by a given qualitative structure, defined by the employees personalities, their education or qualifications.

The labour demand means a quantitative and qualitative need of the economy for employees. Its level is defined by the total number of jobs created in the national economy, i.e. the overall labour demand. The actual labour demand, in turn, is characterised by the number of free jobs, the so-called vacancies. The labour demand derives from two sources, that is the replacement and expansion demand [Unlot, 1998, p. 30]. The replacement demand means that an employer needs new employees, because part of the former staff left the jobs to work for another employer, while part of them have died, retired or are absent from work due to parental leaves or 
disability. In this case, the number of jobs in the economy remains constant. On the contrary, the expansion demand, as its very name suggests, means creation of new jobs and increasing number of the employees. The job creation is related to opening new investments or to the increase in staffing of the existing posts, with the view to more intensive exploitation of machinery by the use of the shift work system.

From the point of view of an enterprise, the labour demand will be linked to strategic decisions about the scale of business activities. These decisions will depend on the volume of the demand for the company's products, the prices of the factors of production and technologies used [Kryńska, Kwiatkowski, 2013, p. 22]. The level of demand for companies goods and services constitutes the main determinant of the decisions related to the number of jobs to be created. The growing demand for goods and services will imply the production growth, which in turn may translate into increased demand for workers. Conversely, the fall in production may lead to a decrease in the demand for labour.

Another factor influencing the size of the demand for labour are the prices of the production factors and the relations between these factors. The job creation decisions are determined in particular by the relations between wages and the prices of the physical capital (e.g. machines and equipment). If the wage level is relatively high as compared to the price of physical capital, a more cost effective solution is to invest in machinery and equipment rather than in the human factor. It is obvious that the proportion of financial capital involved in these two production factors will depend on the technology used by the company (labour intensive vs. capital intensive technologies). In the case of labour intensive technologies the demand for labour may grow, whereas in the case of capital intensive ones, the demand for physical capital will play a more important role.

To sum up, the demand for labour in the economy depends on:

- overall economic situation - when the economic situation is favourable, new jobs are created and thus labour demand grows;

- changes in the structure of the economy - the collapse or shutting down of certain sectors of the economy lead to the closure of enterprises and, as a consequence, to the decrease in the number of jobs;

- volume and structure of natural decreases of labour force;

- profitability of substitution of labour with physical capital;

- level of mechanisation, automatisation and computerisation - the higher their levels, the lower the demand for labour.

\subsection{Labour market determinants}

The above considerations lead us to the conclusion that the shape of the labour market is influenced by three groups of determinants:

- demographic;

- economic;

- social.

\subsubsection{Economic determinants}

Among the economic determinants we find:

- economic structure;

- general economic situation;

- economic infrastructure. 


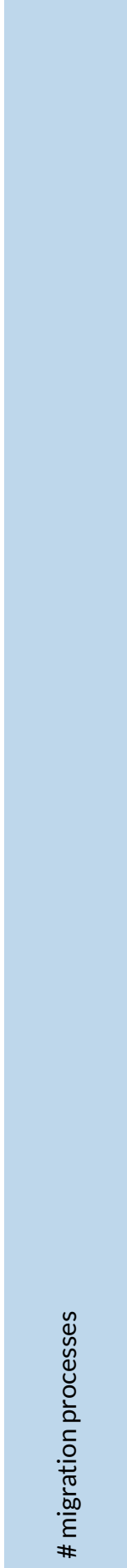

The foregoing factors exert direct impact on the functioning of the economy and determine the demand for labour resources. They are decisive for labour absorption capacity in the regional and local economies, as well as, for the employment structures, that is the demand for employees in different sectors of the economy.

The economic structure, determined by the type of business activities, their territorial distribution and ownership structures, influences considerably the labour absorption capacity. This, in turn, decides about the demand for labour force in qualitative and quantitative dimensions (level of education, type of professional qualifications).

The overall economic situation may influence considerably the demand for labour, which varies in time: it lowers during crisis times (reaching its minimum level during depression) and rises during the economic recovery period, to reach the maximum level at the phase of economic boom.

Economic infrastructure consists of transport, energy, irrigation, melioration and municipal facilities (waterworks, sewerage and gas pipelines), enabling and securing the functioning of production and exchange processes, as well as, other forms of social activity. It is of vital importance for the development of the labour market, because this infrastructure itself can create jobs. At the same time, it indirectly influences job creation by other entities, established as a result of conditions for business activities that are generated by the appropriate infrastructure facilities. Thus, infrastructure encourages location of new businesses and institutions and, by the same token, creation of new jobs.

The analysis of economic determinants should make it possible to define the economic features of the labour market at the region, county or commune levels, as well as, to identify the wealth level of the inhabitants of these territorial units.

\subsubsection{Demographic determinants}

The most important demographic aspects of the labour market include:

- total population;

- gender and age structure of the population;

- urban and rural population ratio;

migration propensity.

The demographic features of the population constitute the key element for labour market studies, because the state and structure of the population are basic constituents of the labour market supply side. Particular importance belongs to the analysis of the age structures, whereby the population is divided into the pre-working, working and post-working. Such a division enables the identification of:

- persons not yet present on the labour market, who will enter it in a few or several years' perspective;

- persons already present on the labour market, both the economically active and the unemployed alike;

- persons, who are still working, despite having reached the post-working age.

Taking the demographic factors into account while analysing the national, regional and local labour markets, makes it possible to determine the volume of the currently available and future labour force. Its size may vary due to the mobility of the individuals offering their work on the labour market. An important role in this respect belongs to migration processes. They include the population movements, that is flows across the boundaries of administrative units within the territory of a single country or migrations across the national boundaries with the aim of changing the permanent residence or with the view of temporary habitation. 
Migrations can be analysed according to various criteria, with the most frequently used being: time, place and reason. From the point of view of the time spent in the new place of residence, we can distinguish between the permanent migrations (resulting in the permanent change of the place of residence) and temporary migrations (seasonal or short-stay migrations). In turn, according to the area where the migrations take place, we can divide them into external (international ones) and internal (within one country territory). Internal migrations can take the form of inter-regional migrations (between regions/voivodships) and the intraregional ones. The Central Statistical Office of Poland distinguishes between the following migration directions: from urban to rural areas, from rural to urban areas, as well as, migration from one urban area to another. The pendulum migrations include the daily commuting to locations outside the place of permanent residence. This type of migration belongs to internal migrations.

The migration (population movement) intensity is measured by migration rate, computed as the quotient of migrants and the average number of population in a given time interval and within a given territory. The direction of population movements are defined by the concepts of inflows and outflows. The difference between the number of persons arriving for permanent residence (inflow) and moving out permanently (outflow) constitutes the net migration rate. Depending on the inflow or outflow being larger, the net migration is either the migration-based population increase or decrease.

\subsubsection{Educational determinants}

Education covers the entirety of processes and activities, aimed at shaping people, in particular the children and youth [Okoń, 2001, p. 87]. The widely understood education involves all processes aiming at such a development and exploitation of individuals' and human groups' capabilities, which would enable them to become to the maximum possible extent - conscious and creative members of the society, able to undertake active self-realization and to build up a unique, sustainable identity and individuality. These processes are shaped by the education system, which, besides the relevant laws, establishes a number of various institutions and persons that function within the system.

The national educational system plays an important role in the national economy. Its main function is to educate the appropriate number of school-leavers to feed the supply side of the labour market and to satisfy the employers' needs. The core of the education process is the pursuit to provide comprehensive formation and development of pupils and subsequently to undertake measures directed at vocational training of the youth, which is of key importance for building-up human resources for the economy. Therefore, an important role - in all education systems - belongs to the so called vocational training system.

Vocational education and training - as a rule - is provided by schools. The Polish school system distinguishes between three levels of vocational education:

- basic (basic vocational schools);

- secondary - secondary vocational schools (secondary technical schools and specialised comprehensive schools; post-secondary vocational colleges);

- higher - technical higher education institutions (e.g. universities of technology).

An important supplement of vocational education within the education system is the vocational training provided by the business sector, that is by various crafts professionals. In this case, thanks to the use of the qualifying potential of craftsmen, the students are being prepared to perform certain professional roles. 
Educational determinants are directly linked with other determinants, in particular with the economic ones. There is a number of relations and closed-loop feedbacks between the economy, labour market and the education system. The qualitative structure of the labour resources supply is shaped by the education system. The structural unemployment occurs in the market, when the structure of the education system is not adequate to the qualitative structure of the demand for labour. In order to assess the efficiency of the education system and its impact on the labour market, one may conduct analyses of the number and structure of school-leavers at various levels, who become potential job-seekers, and the demand for people equipped with certain qualifications. These individuals can also move to other labour markets, neighbouring their place of residence or those where the demand for a particular type of human capital they possess exists.

\subsection{The situation in the labour market and its measurements}

\subsubsection{Balance on the labour market}

The labour market reflects the relations between the demand for labour and labour supply. Depending on type of mutual relations between these two categories, the situation in the labour market may be characterised by one of the following:

- Equilibrium between labour demand and supply, occurring when the number of vacancies equals the number of persons looking for jobs;

- Labour shortage, when the number of vacancies exceeds the number of jobseeking persons, i.e. labour demand is lower than labour supply;

- Labour surplus, when the number of vacancies (demand) is lower than the number of job seekers (supply).

In the first case, we observe a perfect situation, where the needs of employers and employees are fully satisfied. This state, however, is meaningful only theoretically, as in the long term it is not achievable. This is caused by the dynamics of the relations between the demand for labour and labour supply, resulting in constant changes of these relations, which can only approach the equilibrium.

The labour shortage is typical for the centrally planned economy. This state may imply full employment, which over time transforms into overemployment (which, in fact, represents hidden unemployment).

The labour surplus is characteristic for a market economy. It means that on the market there are free labour resources, which are not engaged in widely understood production process. This implies unemployment in the labour market.

\subsubsection{Unemployment and its types}

The literature provides a number of definitions of unemployment. Most often, however, it is assumed that the following features are characteristic for this category [Kwiatkowski, 2002, p. 13]:

- joblessness;

- job searching;

- readiness to work.

Unemployment may be classified according to various criteria. From the point of view of unemployment causes, we can distinguish between the following types of unemployment: frictional, structural, cyclical and seasonal.

Frictional (transitional, natural) unemployment results from the dynamics of the labour market. It refers to the natural mobility of the labour force, possible thanks to 
the labour market mechanisms and the freedom to change the workplace. It occurs irrespective of the economic cycle and results from the short-term discontinuities in employment, originating from the mismatch between labour supply and demand. Frictional unemployment is the after-effect of continuous processes of creation of new and liquidation of some jobs, inflows or outflows of labour resources from the labour market and changes of workplace by the employees. Due to these processes, in a dynamic economy there are always certain amounts of vacancies and unemployed persons alike. This may be caused by the lack of labour market transparency, including the lack of information on vacant jobs, which means that certain period of time elapses before the unemployed are able to find new jobs.

Structural unemployment occurs when the structure of demand for labour does not correspond to the structure of labour supply. It is caused by transformations of the economic structures, reflected in the decline and development of some sectors and branches of the economy. These changes follow the signals sent by commodity markets or result from the state structural policy, changes in the international division of labour and technological development.

Cyclical unemployment results from insufficient aggregate demand and is closely linked to the economic cycle. In the expansion phase this type of unemployment falls down, while employment reaches the highest possible level. Conversely, during the recession phase we observe the slowdown of growth or the fall of production, which in turn leads to a decrease in demand for labour and consequently, raising unemployment.

Seasonal (periodic) unemployment is characterised by a cyclical nature and results from the seasonality of production, directly or indirectly dependant on climatic conditions. It usually occurs in such sectors as agriculture, construction or tourism. The seasonal nature of unemployment is often observed among the graduates.

An important category is the equilibrium unemployment, referring to the Phillips curve describing the relation between inflation and unemployment. In 1970s, Friedman and Phelps, on the basis of monetarist theory of inflation, challenged the occurrence of interchangeability of inflation and unemployment [Friedman, 1968]. Completing the model with the concept of money illusion made it possible to prove, on theoretical grounds, that interchangeability of inflation and unemployment in the long run cannot occur. Assuming that wages are flexible, expectations as to the level of prices in the economy may be false only in the short run due to imperfect information, whereas in the long run it is not possible that the employees would falsely identify the nominal wage with the real one.

Adaptative expectations, consisting in anticipation of future inflation, lead to the return to the state of equilibrium through gradual shift of the short-term Phillips curve upwards by the value of current and expected inflation (in Fig. 9.2 this is expressed by the shift of SRPC1 curve to SRPC2 position and later to the position of SRPC3).

Consequently, in the long run, the Phillips curve turns into a straight vertical line, while unemployment stabilises at the level of the equilibrium unemployment [Phelps, 1968, p. 706]. This takes place with the natural rate of unemployment, including the inevitable level of frictional and structural unemployment, resulting from the fact that in reality the economy functions differently from the model of perfect competition [Kwiatkowski, 2002, p. 150] (in Fig. 9.2 the long-term Phillips LRPC curve crosses the $X$ axis, determining the value of the natural unemployment rate Un).

The natural rate of unemployment is characteristic for the state of equilibrium, whereas its level results from the structural changes in the labour market, as well as, in the commodity and services markets. This is because it depends on real factors 
and not on inflation level or the dynamics of wage growth. The real factors determining the volume of natural rate of unemployment are: the system of unemployment benefits, legislation on minimum wage, degree of labour market regulation, efficiency of labour services, economic mobility of the population, tax systems, the position and strength of trade unions, etc.

\section{Figure 9.2. Phillips curve and natural rate of unemployment}

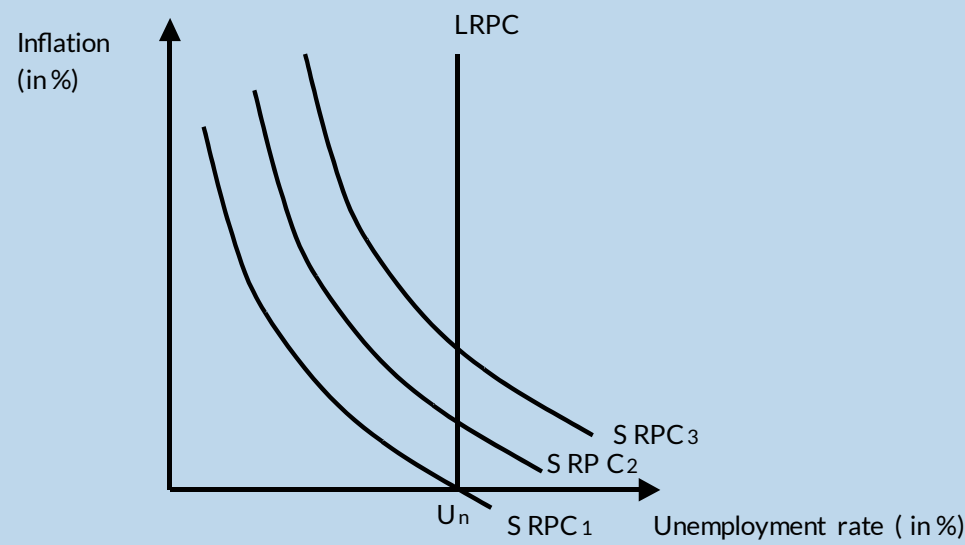

Source: own elaboration based on Kwiatkowski, 2002, p. 142.

In the mid 1980s, the NAIRU (Non-Accelerating Inflation Rate of Unemployment) theory was formulated, that is the concept of unemployment rate, which does not intensify inflation. NAIRU is also an equilibrium unemployment rate, at which inflation remains on the same level. When the unemployment rate remains below NAIRU, it leads to the increase of inflation. In the opposite situation (unemployment rate above NAIRU) disinflation occurs (Fig. 9.3). The NAIRU theory implies that decreasing of inflation inevitably involves the raise of the unemployment rate above NAIRU.

\section{Figure 9.2. Phillips curve and natural rate of unemployment}

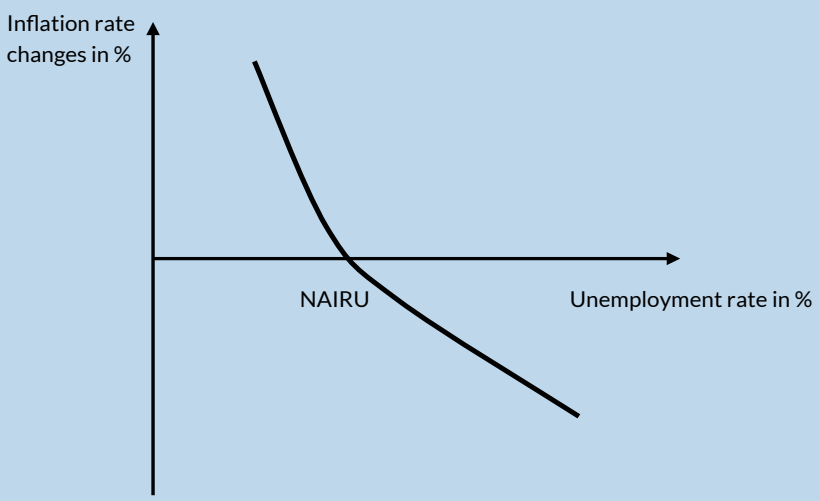




\subsubsection{Labour market measurements}

The assessment of the situation in the labour market requires the use of appropriate measurements. They can take the form of absolute numbers, which are important for the presentation of the scale of certain phenomena occurring in the labour market. Not always, however, these values can constitute the basis for comparison of the discussed phenomena, for example in the spatial cross-section. In such a case one needs to use relative numbers, expressed in the form of indices. They are calculated as a comparison of two absolute numbers, and enable the assessment of intensity of one phenomenon against the other. Such indices are indispensable for comparisons made in time and space. The relative numbers in labour market analyses usually take the form of structure and intensity indices [Makać, 1996, p. 176].

Structure index: the percentage ratio of a part of a population to the total size of this population. A structure index is for example, the percentage share of long-term unemployed persons $\left(L_{i j}\right)$ in the total population of those registered as unemployed $\left(L_{i}\right)$ :

$$
W_{i k}=\frac{L_{i j}}{L_{i}}
$$

Intensity index: the quotient of two logically linked populations, multiplied by a constant number: 1, 100, 1000 or 10000 . In labour market research the following intensity indices are used: participation rate, employment rate, unemployment rate.

Participation rate is the percentage ratio of economically active persons $(L F)$ to the number of population aged 15 and over $(L P)$ (this definition enables calculation of the participation rate on the basis of Labour Force Survey (LFS) information). By the economically active we mean people employed and unemployed:

$$
W_{e a}=\frac{L F}{L P}
$$

Employment rate is the percentage ratio of the number of employed persons $(E)$ to the total number of population aged 15 and over $(L P)$ (this definition enables calculation of the activity index on the basis of $L F S$ information):

$$
W_{e}=\frac{E}{L P}
$$

Unemployment rate is the percentage ratio of the number of unemployed persons $(U)$ to the overall number of those economically active $(L F)$ :

$$
u=\frac{U}{L F}
$$

\subsection{Labour markets of big cities in Poland}

Big cities create labour markets (in spatial terms they are classified as local labour markets), which, - from the point of view of both the demand and supply sides, - typically display specific features as compared to labour markets of rural areas or smaller towns.

Big cities are equipped with the well developed economic base and - in most cases - operate as regional economic centres. Due to their nature, business activities in cities usually concentrate in the services sector (market and non-market). Industrial activity is less important and usually takes place in specially designated 
industrial zones, typically located on the outskirts of the cities (an interesting exception is Lodz, where, due to historical circumstances, part of industrial zones are located relatively close to the city centre).

\section{Labour market of Polish cities vis-à-vis European cities}

Vienna University of Technology since 2007 has been developing the European Smart City Model that provides an integrative approach to profile and benchmark European cities. In 2015, the progress of 9 large towns and cities of Poland (with population between 300 thousands and 1 million) was benchmarked, against a number of dimensions of the smart city concept (more on smart city in: EkoMiasto\#Społeczeństwo, chapter on: Information society in cities). In the smart economy dimension one of the assessment indicators was the situation on the labour market. On the scale ranging from -2 to 2 , the best results were recorded for Gdansk and Bydgoszcz.

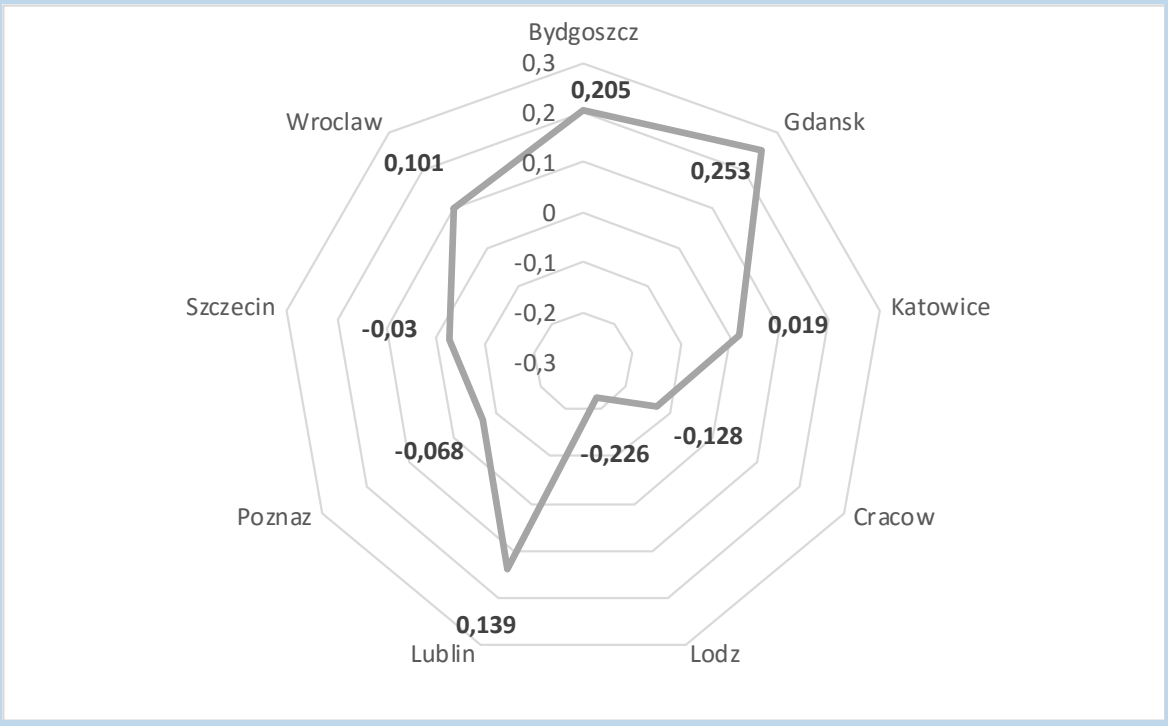

Apart from these cities, the result over 0 was recorded in Lublin, Wroclaw and Katowice. The worst relative situation on the local labour market was observed in Lodz (0.226).

Source: own elaboration after http:/ / smart-cities.eu/ index.php?cid $=7$ G ver $=4$.

Agriculture has been practically moved outside the city boundaries. The labour markets of big cities demonstrate higher absorptive power as compared with other neighbouring labour markets and, - as a rule, - offer more attractive jobs, guaranteeing better chances of promotion and professional development.

Due to the structure of business activities run in big cities, these areas are characterised by relatively high demand for highly qualified labour force - that is the employees holding university degrees and equipped with appropriate professional experience. At the same time, large cities are also academic centres, where higher education institutions provide potential employees equipped with high qualifica- 
tions for the local (and other) labour markets. And even if the supply of highly qualified personnel is relatively high in big cities, the high demand for qualifications results in higher salary levels than in smaller towns or in rural areas. This phenomenon is referred to as urban wage premium [Eeckhout, 2014]. As a rule, in big cities, the unemployment rate is lower than that in the entire economy.

In Poland, 5 cities: - Cracow, Lodz, Poznan, Warsaw and Wroclaw - are included in the category of big cities (with the population over 500 thousand, as of 31 December 2014). The labour markets of these cities bear the characteristics of big city labour markets, while according to selected indicators, significant divergence can be observed between individual cities. Although, owing to the methodology of measuring of the indicators such as participation rate or employment rate, it is not possible to analyse them at the city level, we can still draw a conclusion that Lodz visibly records much worse results than the national average.

\section{Graph 9.1. Employment structure by sectors in 2013 (in \%)}

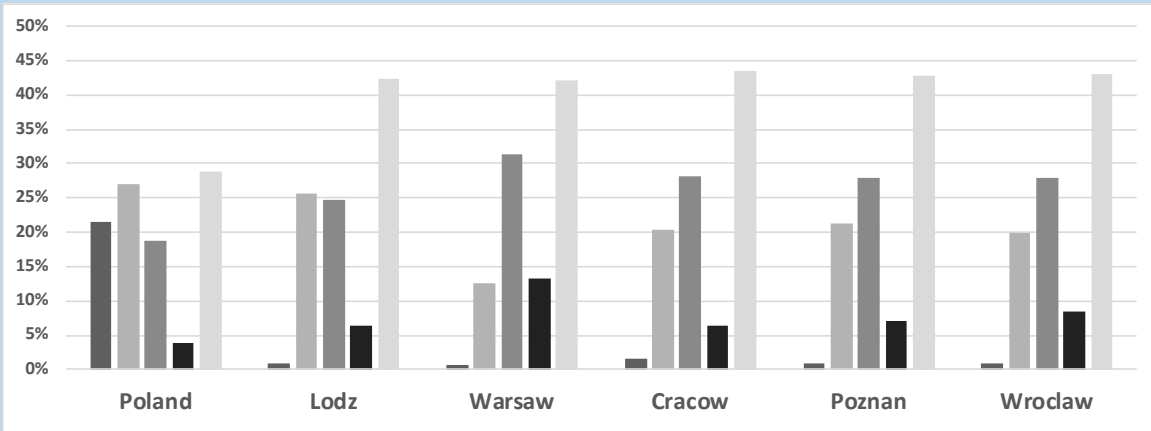

agriculture, forestry and fishing

industry and construction

trade; repair of motor vehicles; transportation and storage; accommodation and catering; information and communication

Source: own elaboration based on Local Data Bank data by Central Statistical Office of Poland.

The structure of employment in the big cities in Poland is definitely dominated with services. - The share of those employed in the services sector ranges from $74 \%$ in Lodz to $87 \%$ in Warsaw, with the national average of $52 \%$. The share of employment in agriculture in all cities fluctuates around 1\%, whilst the employment in industry and construction ranges from $13 \%$ in Warsaw to $26 \%$ in Lodz (Graph 9.1). It is clearly visible that the employment structures in big cities differ considerably from that in the national labour market.

The risk of unemployment in Poland's big cities (with the exception of Lodz) is noticeably lower than that in the national labour market. The unemployment rate, reflecting the labour market situation, deriving in turn from the overall economic 
conditions, was the lowest in 2008, with the figure of $1.8 \%$ for Poznan, $1.9 \%$ for Warsaw, $2.8 \%$ for Cracow and 3.3\% for Wroclaw. Therefore, it is possible to conclude that this was the level oscillating around the equilibrium unemployment, with the frictional nature of the unemployment in these cities prevailing. On the other hand, in Lodz, the unemployment rate reached the level of $6.8 \%$ in 2008 , almost four times higher than in Poznan, yet still below the national average. As the result of the global economic crisis, the situation in Poland's labour market, but also in big cities, deteriorated, which was reflected in the increase of the registered unemployment rate between 2009 and 2013 (in Warsaw up to the level of 4.7\% in 2013, in Cracow up to $5.8 \%$, in Poznan 4.2\% in 2012-2013, in Wroclaw 5.7\% in 2012, while in Lodz it went up to the level of $12.3 \%$ in 2013). It was only in 2014 , when we could observe the downward trend of the unemployment rate (Graph 9.2).

\section{Graph 9.2. Registered unemployment rate in Poland's big cities in 2004-2014 (in \%)}

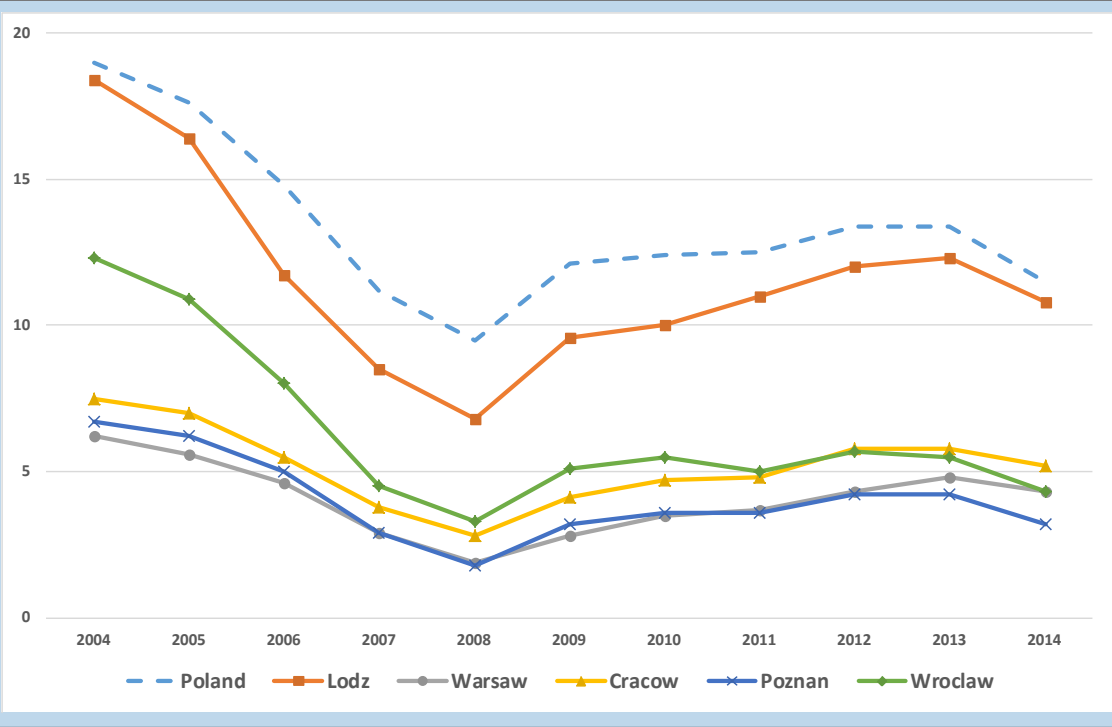

Source: Local Data Bank data by Central Statistical Office of Poland.

As already mentioned, a characteristic feature of big cities' labour market is the urban wage premium - which means that the remunerations in these markets are higher than the average for the entire economy. Such a situation is observed in Poland's big cities, except Lodz, where in 2014 the average pay amounted to $95.8 \%$ of the national average only. On the other end we find Warsaw, with the highest remuneration level (134.5\% of the national average). A similar pay level was observed in Poznan and Wroclaw, and a slightly lower (yet still over the average) in Cracow (Graph 9.3).

On the other hand, the comparison of average remuneration (in real terms) in Poland's big cities between 2004 and 2014, suggests that, although the pay level in Warsaw exceeded significantly the national average within the entire period, its growth was the lowest among all cities discussed (and lower than the national average of $30 \%$ ) and amounted to $22 \%$ only. At the same time the wage growth observed in Wroclaw reached 35\%, in Cracow: $32 \%$, in Lodz: $31 \%$ and in Poznan: $30 \%$. This means that we witness the slow process of the wage convergence across big cities in Poland, that is the decrease of real wage differentials between different cities (Graph 9.4). 


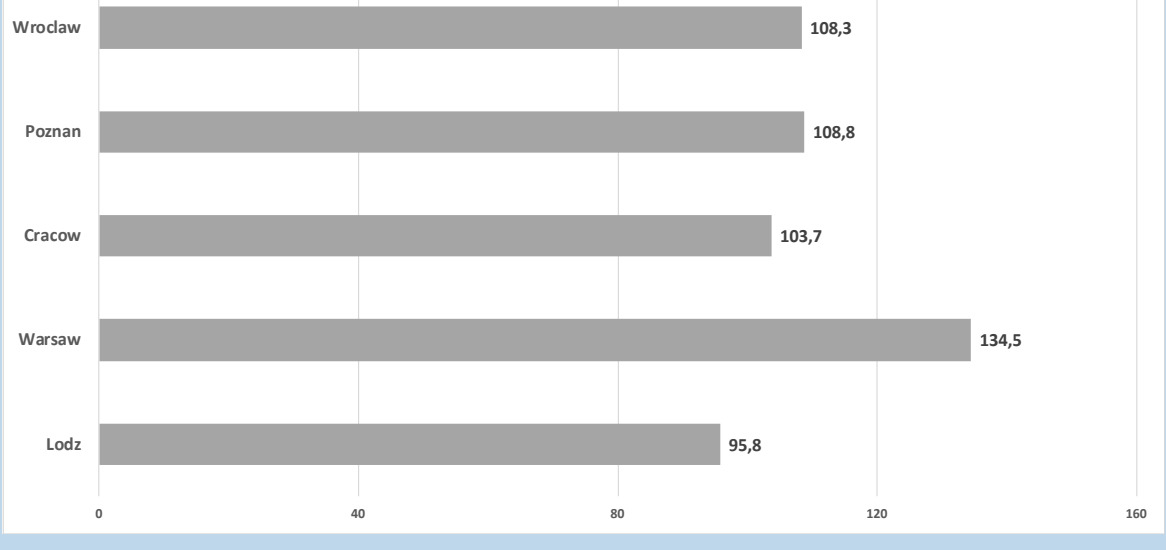

Source: Local Data Bank data by Central Statistical Office of Poland.

Graph 9.4. Gross average monthly wages in 2004-2014 (2004=100)

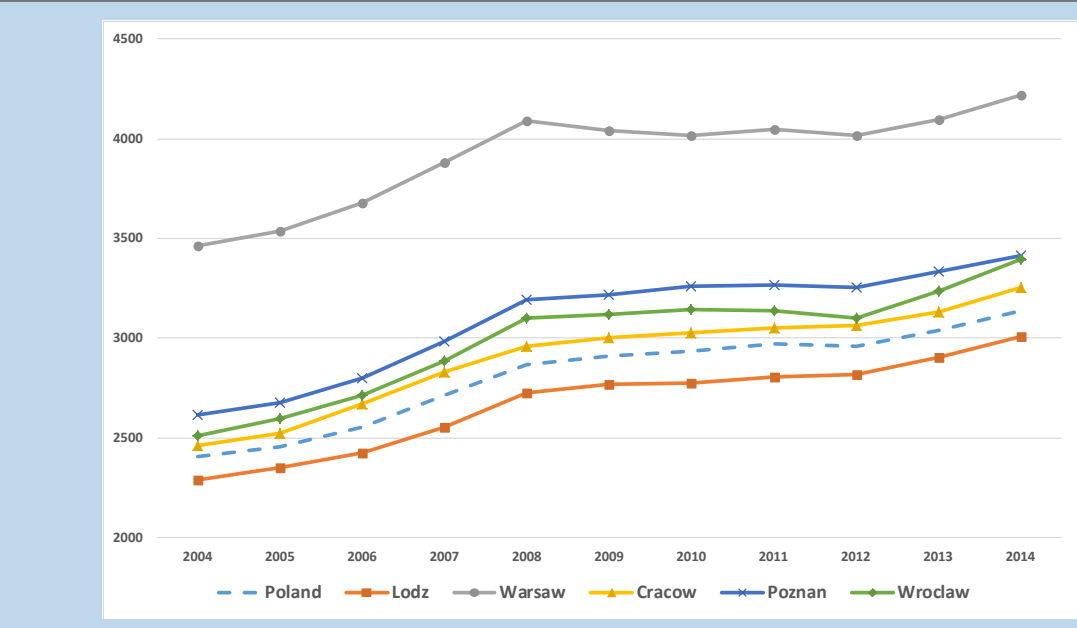

Source: own elaboration based on Local Data Bank data by Central Statistical Office of Poland.

High wages, as compared to the national average, and other aforementioned factors, such as absorptive powers of the market, more attractive jobs (providing better chances for promotion and professional development), classified with the push-pull model as the so-called pull factors, make big cities attractive places to settle in for the inflowing population. The push-pull model defines also the factors pushing people out of their hitherto residence. These are, among others, unfavourable situation on the local labour market, difficulties in finding a job, in particular 
in the learned professions, which is of particular importance for highly qualified workers, for whose competences there is no demand on the local labour market. All these can contribute to big cities being seen as attractive places to settle in for the incoming population (both within internal and external migrations).

The analysis of net permanent migration indicates that in the case of Warsaw, Cracow and Wroclaw there is a surplus of those incoming over those leaving, with the largest net inward migration observed in Warsaw (5.2 in 2014). Lodz and Poznan, within the entire period of 2004-2014 were characterised by the negative balance of permanent migration (Graph 9.5).

Graph 9.5. Net permanent migrations per 1000 persons in 5 big cities of Poland between $2004-2014$

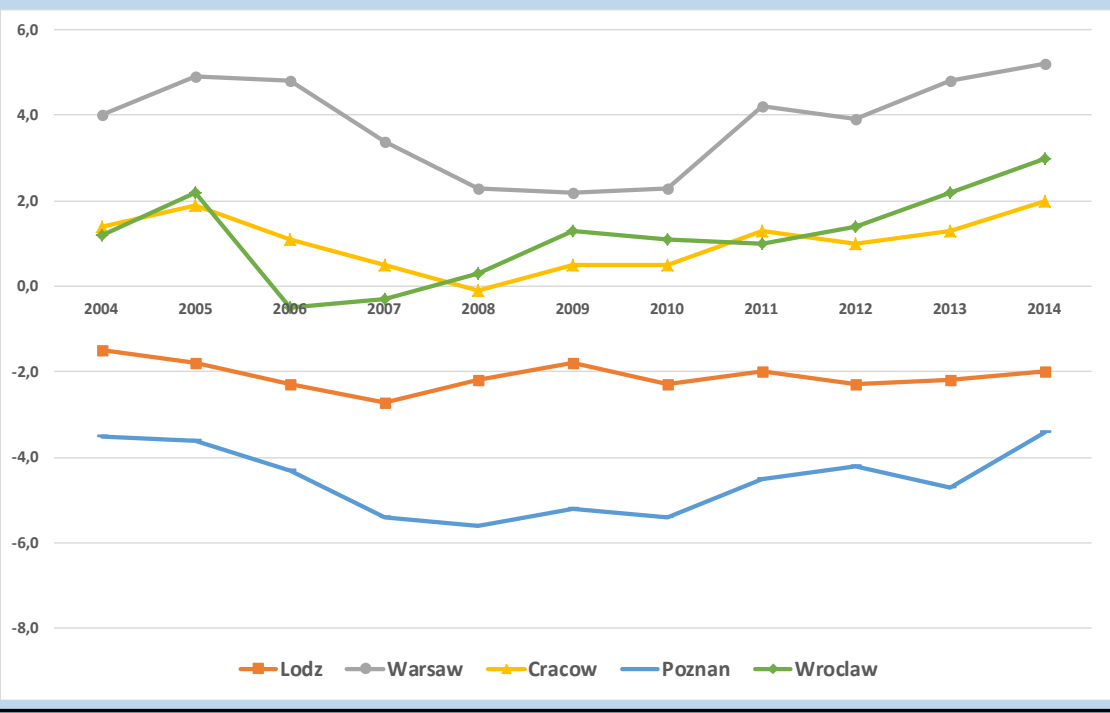

Source: Local Data Banke data by Central Statistical Office of Poland.

It should be stressed that the negative balance of migration in these cities does not necessarily mean that they are not attractive for the migrating labour force. This is rather linked to the suburbanisation processes. They result from the fact that for part of city inhabitants (in particular those of middle and upper classes, according to W. Warner classification) the cities constitute an attractive place of work, but a less attractive place of residence. Consequently, part of the inhabitants move away from big cities to satellite areas, usually located in neighbouring counties, and undertake the hardships of commuting.

Moreover, part of those, who - having undertaken employment in the city decide to change their place of residence, usually choose right away to live in the areas surrounding big cities. As a result, the net outward migrations in big cities are accompanied by positive net migration recorded for the neighbouring counties. This, in turn, leads to the increase of pendulum migrations - that is daily commuting to work, usually from the neighbouring areas.

The only available data on the scale of pendulum migrations to big cities in Poland date back to 2006 . Even if these data are outdated, it is still possible to observe that the scale of this phenomenon was quite significant. 
The balance of arrivals and departures to work in Warsaw amounted to almost 150 thousand persons, with ratio of commuters to Warsaw to those commuting to work outside the city of Warsaw as 13.07.

The scale of pendulum migrations in other big cities was considerably lower than in Warsaw, but still significant in relation to the local labour markets of these cities (Graph 9.6).

\section{Graph 9.6. Pendulum migrations in Poland's big cities in 2006}

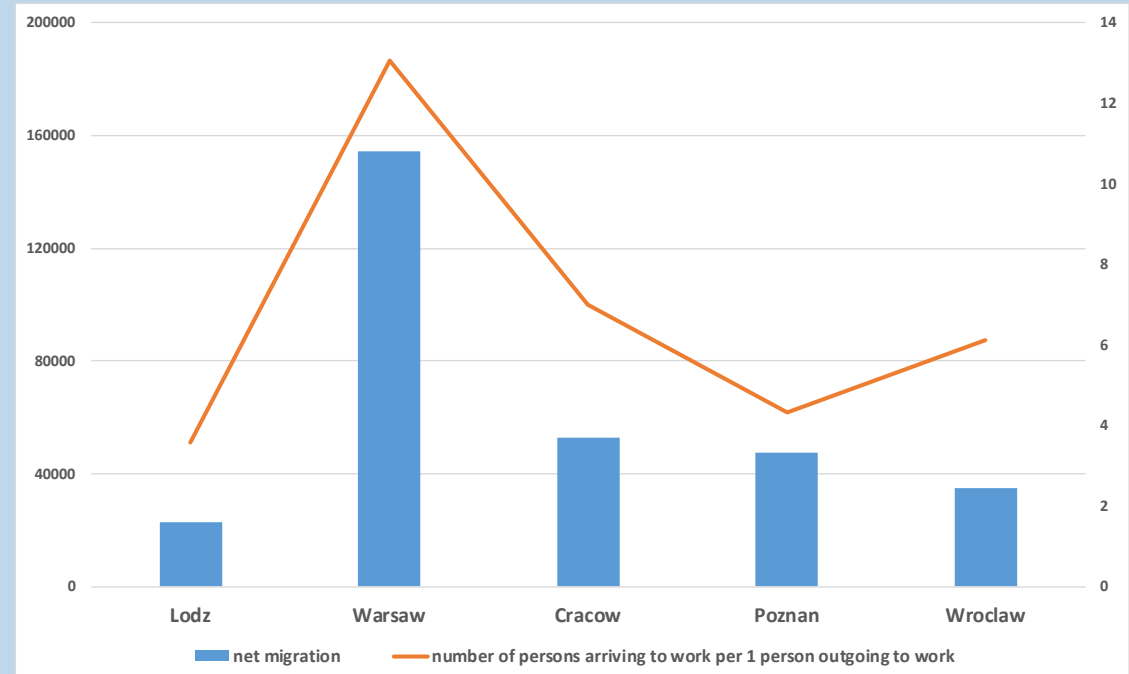

Source: Local Data Bank data by Central Statistical Office of Poland.

\section{Bibliography}

Dziewulak D. (2013), Kształcenie zawodowe w Polsce i w wybranych krajach Unii Europejskiej, Biuro Analiz Sejmowych, Warszawa, http://parl.sejm.gov.pl/WydBAS. nsf/O/9BAF4B83D07F5123C1257B5F002E884F/\$file/Analiza_BAS_2013_95. pdf. Data dostępu: 20.08 .2015 r.

Eeckhout J. (2014), Local labour markets, “Els Opuscles del CREI”, No. 38.

Friedman M. (1968), The Role of Monetary Policy, "American Economic Review", Vol. LVIII, No. 1.

Jarmołowicz W. (ed.) (2007), Gospodarowanie praca we współczesnym przedsiębiorstwie, Wydawnictwo Forum Naukowe, Poznań.

Jarmołowicz W., Knapińska M. (2005), Polityka państwa na rynku pracy w warunkach transformacji i integracji gospodarczej, Wydawnictwo Akademii Ekonomicznej w Poznaniu, Poznań.

Kwiatkowski E. (2002), Bezrobocie. Podstawy teoretyczne, Wydawnictwo Naukowe PWN, Warszawa. 
Kryńska E., Kwiatkowski E. (2013), Podstawy wiedzy o rynku pracy, Wydawnictwo Uniwersytetu Łódzkiego, Łódź.

Makać W. (1996), Podstawowe metody statystyczne w analizie rynku pracy, Krajowy Urząd Pracy, Warszawa.

Okoń W. (2001), Mały słownik pedagogiczny, Wydawnictwo Żak, Warszawa.

Phelps E.S. (1968), Money-Wage Dynamics and Labor-Market Equilibrum, "The Journal of Political Economy", Vol. 76, No. 4, part II, July/August.

Unolt J. (1998), Ekonomiczne problemy rynku pracy, BPS, Katowice.

Zieliński M. (2012), Rynek pracy w teoriach ekonomicznych, CeDeWu, Warszawa. 


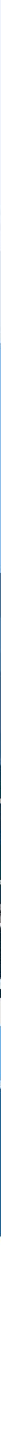

